\title{
KESIAPAN AKSESIBILITAS JALUR PEDESTRIAN KAWASAN TRANSIT TERMINAL TIRTONADI, KOTA SURAKARTA BERDASARKAN KONSEP TRANSIT ORIENTED DEVELOPMENT (TOD)
}

\author{
Andindita Aulia Dewi ${ }^{1}$, Soedwiwahjono ${ }^{1}$, Kuswanto Nurhadi $^{2}$ \\ 1Program Studi Perencanaan Wilayah dan Kota, Fakultas Teknik, Universitas Sebelas Maret \\ 2Program Studi Teknik Sipil, Fakultas Teknik, Universitas Sebelas Maret
}

\begin{abstract}
Abstrak
Transit Oriented Development (TOD) merupakan konsep ruang kota yang berorientasi pada pejalan kaki dan pengguna transportasi publik. Salah satu klasifikasi area TOD ialah kawasan transit, kawasan dengan stasiun transit dan penggunaan lahan yang mendorong aktivitas transit. Kota Surakarta merupakan salah satu kota yang menerapkan konsep TOD dalam pengembangan kawasan. Dirjen Perhubungan Darat Kementerian Perhubungan RI menetapkan Terminal Tirtonadi sebagai kawasan transit dengan konsep TOD. Konsep TOD menekankan pentingnya berjalan kaki yang ditunjang dengan adanya jalur pedestrian. Jalur pedestrian berguna untuk meningkatkan aksesibilitas di kawasan transit. Penelitian ini bertujuan untuk mengetahui kesiapan aksesibilitas jalur pedestrian di kawasan transit Kota Surakarta berdasarkan Konsep TOD. Penelitian ini merupakan penelitian kuantitatif dengan menjabarkan variabel menjadi indikator-indikator terukur. Penelitian ini menggunakan pendekatan deduktif serta teknik analisis skoring dan deskriptif. Data dalam penelitian diperoleh melalui observasi. Hasil perhitungan skoring menunjukan bahwa tingkat kesiapan tiap kriteria berbeda-beda dan menunjukan bahwa aksesibilitas jalur pedestrian di kawasan transit Terminal Tirtonadi berdasarkan konsep TOD tergolong belum siap, dari delapan kriteria kesiapan, tiga kriteria tergolong tidak siap, tiga kriteria lainnya tergolong belum siap dan dua kriteria tergolong siap. Beberapa faktor yang mempengaruhi kesiapan tersebut berasal dari aspek stakeholder dan rencana.
\end{abstract}

Kata kunci: aksesibilitas; jalur pedestrian; Transit Oriented Development (TOD)

\begin{abstract}
Transit Oriented Development (TOD) is an urban space concept that is oriented on pedestrians and public transportation users. One of the TOD area classifications is transit area, an area with a transit station and land use that pushes transit activities. Surakarta City is one of the cities that applies TOD concept in area development. Dirjen Perhubungan Darat Kementerian Perhubungan RI chose Tirtonadi Bus Terminal as transit area with TOD concept. TOD concept emphasizes the importance of walking which is supported by pedestrian walkways. Pedestrian walkways is used for enhancing the accessibility on transit area. This study aims to measure the readiness of pedestrian walkways accessibility around Surakarta City transit areas based on TOD concept. This study is quantitative study that explains variables to measured indicators. This study uses deductive approach with scoring and descriptive analysis techniques. Data for this study was taken through observation. Scoring result shows that every criterias has varying level of readiness and the result shows that pedestrian walkways accessibility in Tirtonadi Bus Terminal transit area is considered not ready by the TOD concept, from eight criterias, three criterias are considered not ready, three criterias are considered not ready yet, while two criterias are considered ready. Some factors that affected the readiness come from stakeholder and planning aspects.
\end{abstract}

Keywords: accessibility; pedestrian walkways; Transit Oriented Development (TOD)

\section{PENDAHULUAN}

Transit Oriented Development (TOD) merupakan salah satu konsep kota yang berkaitan dengan aktivitas berjalan kaki. Konsep TOD didesain untuk menciptakan ruang kota yang lebih hidup yang berorientasi pada pejalan kaki dan pengguna transportasi publik (Fani, 2016). TOD umumnya didefinisikan sebagai 5D: Density, Diversity, Design, Destination accessibility and Distance to transit (Kepadatan, Keragaman, Desain, Aksesibilitas tempat tujuan, dan Jarak ke tempat transit) (Cervero \& Kockelman, 1997; Litman, 2010 dalam Conesa, 2018). 
Salah satu klasifikasi area kawasan TOD ialah Premium Transit Station, yakni titik transit yang melayani transportasi umum yang banyak digunakan (Florida TOD Guidebook, 2012). Titik transit tersebut bukan hanya sebagai tempat naik dan turunnya penumpang, namun juga memiliki kawasan sekitar yang dapat menunjang aktivitas transit (Jati, 2017). Treasure Coast Regional Planning Council, menjelaskan radius di mana kemampuan pejalan kaki dapat melintasi kawasan dengan nyaman ialah setengah mil atau sekitar 800 meter, dapat ditempuh dalam waktu lima sampai sepuluh menit perjalanan berjalan kaki (TCRPC, 2012 dalam Jati, 2017).

Terkait dengan penerapan Konsep TOD, salah satu kota di Indonesia yang menggunakan konsep TOD dalam perencanaan kotanya ialah Kota Surakarta. Selain tertera dalam RTRW Kota Surakarta Tahun 2011-2031, Terminal Tirtonadi yang menjadi satu-satunya terminal di Kota Surakarta menjadi terminal pertama yang dipilih dari 91 terminal tipe A se-Indonesia, yang akan dikembangkan di bidang komersial melalui konsep TOD sekaligus dijadikan pilot project pengembangan terminal berbasis konsep TOD oleh Dirjen Perhubungan Darat Kementerian Perhubungan RI (Prabawati, 2018). Kawasan di sekitar Terminal Tirtonadi dalam radius 800 meter berpotensi sebagai kawasan transit TOD, karena selain terdapat titik transit, kawasan sekitarnya terdiri dari penggunaan lahan campuran sehingga dapat menunjang aktivitas transit.

Skala spasial TOD yang utama diukur dengan jarak berjalan kaki, sehingga konsep TOD sangat menekankan tentang pentingnya berjalan kaki (Cervero \& Kockelman, 1997 dalam Li, 2016). Sarana yang menunjang aktivitas berjalan kaki ialah jalur pedestrian. Jalur pedestrian bertujuan untuk meningkatkan aksesibilitas di antara area-area terdekat stasiun transit dengan kawasan di sekitarnya (San Francisco Better Street Plan, 2008). Aksesibilitas juga merupakan salah satu dari lima definisi TOD. Aksesibilitas dalam konsep TOD dapat diukur dari mobilitas skala metropolitan dan mobilitas pejalan kaki (Wu, Shen, \& Zu, 2011 dalam Conesa, 2018).

Berdasarkan penjabaran tersebut, dapat diketahui bahwa Kota Surakarta mencanangkan konsep TOD dalam rencana tata ruang kotanya dan Terminal Tirtonadi dijadikan sebagai salah satu Pilot Project di Indonesia. Selain itu juga diketahui jika aksesibilitas jalur pedestrian merupakan hal yang utama dalam konsep TOD, oleh karena itu diperlukan pengkajian lebih dalam mengenai bagaimana kesiapan aksesibilitas jalur pedestrian di kawasan transit Terminal Tirtonadi berdasarkan konsep TOD. Penelitian ini bertujuan untuk mengetahui kesiapan aksesibilitas jalur pedestrian di kawasan transit Terminal Tirtonadi berdasarkan konsep TOD.

\section{KAJIAN PUSTAKA}

\subsection{KESIAPAN}

Menurut Cambridge Dictionary, kesiapan atau readiness memiliki arti kesediaan atau menyatakan sedang disiapkan untuk sesuatu. Dalam bahasa indonesia sendiri kesiapan berasal dari kata dasar "siap" yang menurut Kamus Besar Bahasa Indonesia berarti sudah bersedia (untuk). Menurut U. S. Department of Health and Human Service, kesiapan memiliki arti kemampuan untuk melakukan proses transformasi atau perubahan. Penilaian kesiapan dapat memberi peluang untuk memperbaiki gap atau kesenjangan yang timbul baik sebelum, maupun ketika implemetasi rencana.

Oleh karena itu, yang dimaksud dengan kesiapan aksesibilitas jalur pedestrian ialah kemampuan aksesibilitas jalur pedestrian untuk memenuhi kriteria-kriteria dari konsep TOD. Penilaian kesiapan askesibilitas jalur pedestrian dilakukan untuk melihat kesenjangan yang timbul antara kondisi eksisting dengan kriteria konsep TOD, yang selanjutnya dapat dijadikan sebagai bahan evaluasi untuk memperbaiki kesenjangan tersebut.

\subsection{AKSESIBILITAS JALUR PEDESTRIAN BERDASARKAN KONSEP TRANSIT ORIENTED DEVELOPMENT (TOD)}

Transit Oriented Development merupakan sebuah konsep penataan ruang yang menempatkan pusat kegiatan di sekitar stasiun transit, dimana memiliki karakteristik kompak, penggunaan lahan campuran, dan ramah pejalan kaki dalam radius jarak berjalan kaki dari titik transit (Sideris, 2000 dalam Hasibuan, 2014). Institute for Transportation and Development Policy (ITDP) merekomendasikan jarak berjalan kaki yang ideal ialah $500 \mathrm{~m}-1000 \mathrm{~m}$ dari titik transit (ITDP, 2017). TOD bertujuan untuk menciptakan lingkungan yang mendorong penggunaan transportasi publik seperti bus dan mengurangi penggunaan mobil pribadi melalui peningkatan aksesibilitas dan mobilitas yang baik (Handayeni, 2014). TOD diterapkan di beberapa negara dan dianggap dapat mendorong mobilitas masyarakat dengan nonmotorized movement (berjalan atau bersepeda) dan mengubah penggunaan kendaraan pribadi ke angkutan umum (Ditmarr et al., 2004 dalam Widyahari, 2015). 
Dalam tipologi kawasan TOD terdapat kawasan Transit Neighborhood, yang merupakan kawasan dalam radius di mana pejalan kaki dapat melintasi kawasan dengan nyaman yang ditempuh dalam waktu lima sampai sepuluh menit, yaitu memiliki radius setengah mil $(800 \mathrm{~m})$ dari titik transit (Florida TOD Guidebook, 2012). Oleh karena itu, dalam menentukan radius kawasan transit penelitian ini menggunakan radius $800 \mathrm{~m}$ dari titik transit.

Jalur pedestrian tergolong aksesibel jika memilliki jarak tempuh yang dekat untuk menuju tempat transit (ITDP, 2017). Mondou (2001) berpendapat bahwa $300 \mathrm{~m}$ merupakan jarak berjalan kaki yang dapat diterima. Chapleau dan Morency (2005) berpendapat jika jarak berjalan kaki yang dapat diterima yaitu $500 \mathrm{~m}$, sedangkan jarak rule of thumb yang digunakan oleh para perencana ialah 400 m dan 800 m (El-Geneidy et al., 2009; Hess, 2009; Hsiao et al., 1997; Kimpel et al., 2007; Lovett et al., 2002 dalam Kusuma et al, 2017).

Institute for Transportation \& Develompent Policy (ITDP) dalam TOD Standard v3.0 (2017) menjelaskan prinsipprinsip transportasi perkotaan dan kunci penerapan TOD yaitu menciptakan jaringan jalan dan jalur pedestrian yang memiliki rute bervariasi. Aksesibilitas dalam konsep TOD memiliki arti jauh-dekatnya lingkungan sekitar ke stasiun angkutan umum atau fasilitas umum, dan jarak ke tempat transit. Berbagai jalur pejalan kaki yang berbeda-beda bekerja sama untuk menciptakan jaringan jalur pedestrian yang komprehensif dengan jalur dan rute yang menghubungkan berbagai destinasi. Jaringan jalan yang saling terhubung akan meminimalkan jarak berjalan kaki (NYC Sidewalk Guideline, 2013).

Jalur pedestrian yang aksesibel ialah jalur pedestrian yang mudah untuk diakses, nyaman untuk digunakan, memilliki jarak tempuh yang dekat untuk menuju tempat transit dan bebas hambatan bagi semua kalangan penggunanya. Jalur pedestrian yang mudah diakses berarti lokasi jalur pedestrian yang mudah diraih karena terletak pada lokasi yang strategis, dan tata letak atribut jalur pedestrian yang tidak mengganggu alur pejalan kaki. Jalur pedestrian yang nyaman didukung dengan penyediaan naungan dan bentuk perlindungan dari kondisi iklim yang parah, seperti pohon pelindung dam kanopi (ITDP, 2017).

Metropolitan Atlanta Rapid Transit Authority (2010) menjelaskan, salah satu fungsi terpenting dari TOD adalah untuk menghubungkan sebanyak mungkin orang ke sebanyak mungkin kegiatan, layanan dan tempat dengan mudah. Jalur pedestrian bertujuan untuk meningkatkan aksesibilitas di antara area-area tempat pemberhentian atau stasiun transit, kawasan komersial dan perumahan (Metropolitan Council, 2006). Permen PU No. 3 Tahun 2014 tentang Pedoman Perencanaan, Penyediaan, dan Pemanfaatan Prasarana dan Sarana Jaringan Pejalan Kaki di Kawasan Perkotaan menggolongkan penggunaan lahan yang membutuhkan pengembangan jaringan pejalan kaki yaitu permukiman dan komersial.

Aksesibilitas jalur pedestrian juga ditujukan untuk semua orang dan kalangan, karena menurut ADA Standard (2010) dan the accessible and Usable Buildings and Facilities Standards, 2010 (dalam NYC Sidewalk Guideline, 2013), aksesibilitas jalur pedestrian berarti memastikan jalur pedestrian dapat mengakomodasi pengguna dari berbagai usia dan dari berbagai kemampuan fisik yang berbeda. Bagi pengguna jalur pedestrian berkebutuhan khusus tuna netra dan/atau pengelihatan terganggu (low vision), membutuhkan informasi khusus pada permukaan jalur pedestrian yang disebut lajur pemandu (guiding block) (Pedoman Perencanaan Teknis Fasilitas Pejalan Kaki, 2018). Untuk pejalan kaki yang mengalami gangguan mobilitas dengan alat bantu kursi roda dan untuk pengguna beroda lainnya seperti kereta bayi, dibutuhkan ramp (Western Australia Department of Transport, 2011).

Jaringan pejalan kaki berfungsi untuk memfasilitasi pergerakan pejalan kaki dari satu tempat ke tempat lainnya dengan mudah, aman, nyaman, dan mandiri termasuk untuk penyandang disabilitas (Sung et al., 2011 dalam Chia Nung li, 2016). Agar jalur pedestrian dapat menciptakan lingkungan berjalan kaki yang aman, diperlukan penyangga agar pengguna dapat terlindungi dari volume dan arus kendaraan bermotor (National Association of City Transportation Officials, 2008).

\section{METODE PENELITIAN}

Pendekatan penelitian yang digunakan dalam penelitian ini yaitu pendekatan deduktif. Tahap awal yang dilakukan ialah mengamati isu-isu di sekitar Kota Surakarta mengenai rencana dan pengaplikasian konsep TOD serta jalur pedestrian di kawasan transit, kemudian melakukan eksplorasi teori dan peraturan perundangan terkait jalur pedestrian menurut konsep TOD. Ruang lingkup wilayah studi dalam penelitian ini ialah kawasan transit Terminal Tirtonadi dengan radius $800 \mathrm{~m}$ dari titik transit (lihat Gambar 1). Kawasan transit Terminal Tirtonadi terdiri dari tujuh ruas jalan raya, yaitu 
JI. A. Yani, JI. Popda, Jl. Setiabudi, Jl. Tagore, Jl. Letjen S. Parman, JI. Kapt. P. Tendean dan Jl. Adisucipto, serta terdiri dari satu jembatan yaitu Jembatan Tirtonadi.

Data yang diperlukan diperoleh menggunakan teknik pengumpulan data primer yang dilakukan melalui observasi lapangan. Selanjutnya data akan dianalisis secara kuantitatif, yaitu penjabaran variabel menjadi indikator-indikator yang terukur dan dihitung dengan menggunakan teknik analisis skoring dan analisis deskriptif untuk mengetahui tingkat kesiapan jalur pedestrian di kawasan transit stasiun bus Kota Surakarta berdasarkan konsep TOD. Tabel 1 merupakan variabel dan indikator skoring yang digunakan dalam penelitian ini (lihat Tabel 1).

Substansi yang akan dibahas pada penelitian ini adalah kesiapan aksesibilitas jalur pedestrian di kawasan transit Terminal Tirtonadi. Kriteria yang akan dibahas dalam penelitian ini yaitu jarak berjalan kaki, variasi rute jalur pedestrian, tata letak atribut jalur pedestrian, ketersediaan atribut jalur pedestrian, jenis kelangsungan jalur pedestrian, nilai strategis lokasi jalur pedestrian, pengaruh faktor iklim, aspek kenyamanan bagi disabilitas, aspek kemudahan bagi disabilitas dan keamanan jalur pedestrian.

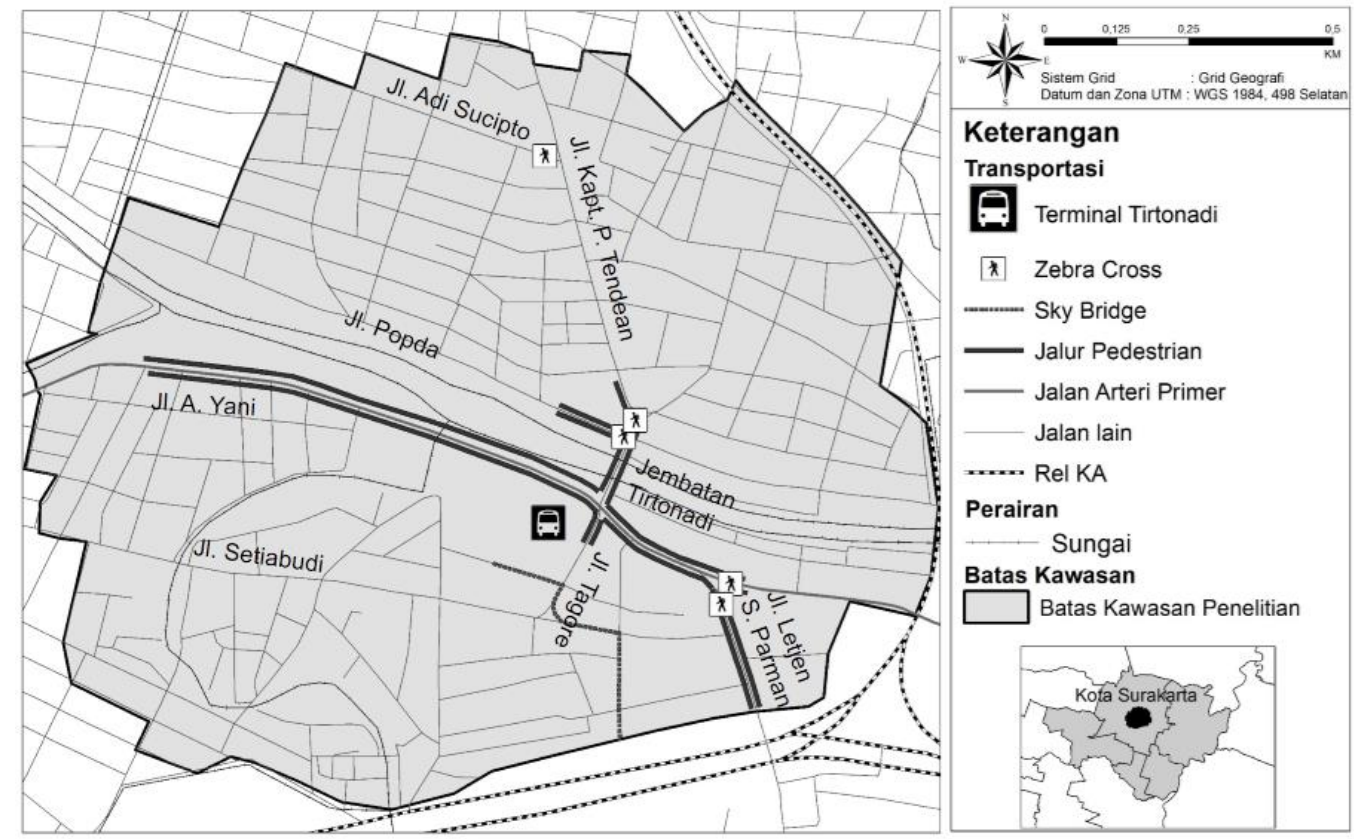

Gambar 1. Peta Ruang Lingkup Wilayah Penelitian

Tabel 1. Variabel dan Indikator Skoring

\begin{tabular}{|c|c|c|c|}
\hline Variabel & $\begin{array}{c}\text { Skor } 1 \\
\text { (Tidak Siap) }\end{array}$ & $\begin{array}{c}\text { Skor } 2 \\
\text { (Belum Siap) }\end{array}$ & $\begin{array}{l}\text { Skor } 3 \\
\text { (Siap) }\end{array}$ \\
\hline Jarak berjalan kaki & $\begin{array}{l}\text { Jalur pedestrian melayani } \\
\text { pejalan kaki untuk dapat } \\
\text { mencapai terminal dengan } \\
\text { jarak lebih dari } 800 \mathrm{~m}\end{array}$ & $\begin{array}{l}\text { Jalur pedestrian melayani } \\
\text { pejalan kaki untuk dapat } \\
\text { mencapai terminal dengan } \\
\text { jarak } 400 \text { hingga } 800 \mathrm{~m}\end{array}$ & $\begin{array}{l}\text { Jalur pedestrian melayani } \\
\text { pejalan kaki untuk dapat } \\
\text { mencapai terminal dengan } \\
\text { jarak kurang dari } 400 \mathrm{~m}\end{array}$ \\
\hline $\begin{array}{l}\text { Variasi rute jalur } \\
\text { pedestrian }\end{array}$ & $\begin{array}{l}\text { Jalur pedestrian dapat dicapai } \\
\text { hanya dengan menggunakan } \\
\text { satu rute berjalan kaki }\end{array}$ & $\begin{array}{l}\text { Jalur pedestrian dapat dicapai } \\
\text { dari dua rute berjalan kaki }\end{array}$ & $\begin{array}{l}\text { Jalur pedestrian dapat dicapai } \\
\text { dari lebih dari dua rute berjalan } \\
\text { kaki yang bervariasi }\end{array}$ \\
\hline $\begin{array}{l}\text { Tata letak atribut jalur } \\
\text { pedestrian }\end{array}$ & $\begin{array}{l}\text { Tidak ada marka, perambuan, } \\
\text { dan papan informasi (signage) } \\
\text { jalur pedestrian di sepanjang } \\
\text { jalur pedestrian dalam satu } \\
\text { ruas jalan }\end{array}$ & $\begin{array}{l}\text { Terdapat marka, perambuan, } \\
\text { dan papan informasi (signage) } \\
\text { jalur pedestrian namun tidak } \\
\text { sesuai dengan kebutuhan } \\
\text { (hanya terdapat satu buah) } \\
\text { dan tidak terlihat dengan jelas } \\
\text { (terhalang atau kondisi tiang } \\
\text { yang rusak) }\end{array}$ & $\begin{array}{l}\text { Terdapat marka, perambuan, } \\
\text { dan papan informasi (signage) } \\
\text { jalur pedestrian yang sesuai } \\
\text { dengan kebutuhan (lebih dari } \\
\text { satu buah), jelas dan terlihat } \\
\text { dengan mudah (tidak terhalang) }\end{array}$ \\
\hline
\end{tabular}




\begin{tabular}{|c|c|c|c|}
\hline Variabel & $\begin{array}{c}\text { Skor } 1 \\
\text { (Tidak Siap) }\end{array}$ & $\begin{array}{c}\text { Skor } 2 \\
\text { (Belum Siap) }\end{array}$ & $\begin{array}{l}\text { Skor } 3 \\
\text { (Siap) }\end{array}$ \\
\hline $\begin{array}{l}\text { Ketersediaan atribut jalur } \\
\text { pedestrian }\end{array}$ & $\begin{array}{l}\text { Tidak terdapat atribut sama } \\
\text { sekali di sepanjang ruas jalan }\end{array}$ & $\begin{array}{l}\text { Terdapat atribut namun dalam } \\
\text { kondisi yang buruk/rusak } \\
\text { sehingga tidak dapat } \\
\text { berfungsi/digunakan }\end{array}$ & $\begin{array}{l}\text { Terdapat beberapa atribut } \\
\text { dalam kondisi baik dan dapat } \\
\text { berfungsi sebagaimana } \\
\text { mestinya }\end{array}$ \\
\hline \multirow[t]{2}{*}{$\begin{array}{l}\text { Jenis kelangsungan jalur } \\
\text { pedestrian }\end{array}$} & $\begin{array}{l}\text { Jalur pedestrian tidak } \\
\text { terhubung dengan jalan } \\
\text { lingkungan/ jalan setapak } \\
\text { dalam kawasan hunian }\end{array}$ & $\begin{array}{l}\text { Jalur pedestrian terhubung } \\
\text { dengan jalan lingkungan pada } \\
\text { kawasan hunian, namun tidak } \\
\text { melayani hinga dalam } \\
\text { kawasan hunian dan harus } \\
\text { berjalan kaki terlebih dahulu } \\
\text { untuk mencapainya }\end{array}$ & $\begin{array}{l}\text { Jalur pedestrian terhubung } \\
\text { langsung dengan jalan } \\
\text { lingkungan/ jalan setapak } \\
\text { dalam kawasan hunian }\end{array}$ \\
\hline & $\begin{array}{l}<34 \% \text { kawasan komersial } \\
\text { terlayani jalur pedestrian }\end{array}$ & $\begin{array}{l}34 \%-67 \% \text { kawasan } \\
\text { komersial terlayani jalur } \\
\text { pedestrian }\end{array}$ & $\begin{array}{l}>67 \% \text { kawasan komersial } \\
\text { terlayani jalur pedestrian }\end{array}$ \\
\hline $\begin{array}{l}\text { Nilai Strategis lokasi jalur } \\
\text { pedestrian }\end{array}$ & $\begin{array}{l}\text { Lokasi jalur pedestrian bukan } \\
\text { terletak pada lokasi dimana } \\
\text { masyarakat melakukan } \\
\text { pergantian moda angkutan } \\
\text { umum dan tidak didukung } \\
\text { dengan adanya area kantong } \\
\text { parkir di sekitarnya }\end{array}$ & $\begin{array}{l}\text { Lokasi jalur pedestrian terletak } \\
\text { pada daerah yang banyak } \\
\text { dilalui masyarakat sebagai } \\
\text { tempat berganti angkutan } \\
\text { umum namun tidak didukung } \\
\text { oleh area kantong parkir di } \\
\text { sekitarnya. }\end{array}$ & $\begin{array}{l}\text { Lokasi jalur pedestrian terletak } \\
\text { pada daerah padat yang } \\
\text { banyak dilalui masyarakat } \\
\text { sebagai tempat berganti } \\
\text { angkutan umum yang didukung } \\
\text { oleh area kantong parkir yang } \\
\text { memadai di sekitarnya }\end{array}$ \\
\hline Pengaruh Faktor iklim & $\begin{array}{l}\text { Tidak terdapat pohon/ kanopi/ } \\
\text { bagian dari bangunan sekitar } \\
\text { yang dapat dijadikan tempat } \\
\text { berteduh dan berlindung dari } \\
\text { panas dan hujan }\end{array}$ & $\begin{array}{l}\text { Terdapat pohon/ kanopi/ } \\
\text { bagian dari bangunan sekitar } \\
\text { tetapi tidak bisa dijadikan } \\
\text { tempat berteduh dan } \\
\text { berlindung dari panas dan } \\
\text { hujan }\end{array}$ & $\begin{array}{l}\text { Terdapat pohon/kanopi/bagian } \\
\text { dari bangunan sekitar yang } \\
\text { dapat dijadikan tempat } \\
\text { berteduh dan berlindung dari } \\
\text { panas dan hujan }\end{array}$ \\
\hline $\begin{array}{l}\text { Aspek kenyamanan bagi } \\
\text { disabilitas }\end{array}$ & $\begin{array}{l}<34 \% \text { Jalur pedestrian bebas } \\
\text { penghalang (oleh tiang, pohon, } \\
\text { parkir dan/atau atribut lainnya) } \\
\text { dan bebas pembatas sehingga } \\
\text { kursi roda dapat melintas } \\
\text { dengan mudah }\end{array}$ & $\begin{array}{l}34 \% \text { - } 67 \% \text { Jalur pedestrian } \\
\text { bebas penghalang (oleh tiang, } \\
\text { pohon, parkir dan/atau atribut } \\
\text { lainnya) dan bebas pembatas } \\
\text { sehingga kursi roda dapat } \\
\text { melintas dengan mudah }\end{array}$ & $\begin{array}{l}>67 \% \text { Jalur pedestrian bebas } \\
\text { penghalang (oleh tiang, pohon, } \\
\text { parkir dan/atau atribut lainnya) } \\
\text { dan bebas pembatas sehingga } \\
\text { kursi roda dapat melintas } \\
\text { dengan mudah }\end{array}$ \\
\hline \multirow[t]{2}{*}{$\begin{array}{l}\text { Aspek kemudahan bagi } \\
\text { disabilitas }\end{array}$} & $\begin{array}{l}\text { Tidak terdapat ramp di seluruh } \\
\text { ruas jalur pedestrian dalam } \\
\text { kawasan transit }\end{array}$ & $\begin{array}{l}\text { Terdapat ramp dalam kondisi } \\
\text { yang buruk/rusak sehingga } \\
\text { pengguna kursi roda sulit } \\
\text { menggunakannya untuk } \\
\text { melewati jalur pedestrian } \\
\text { dalam kawasan transit }\end{array}$ & $\begin{array}{l}\text { Terdapat ramp dalam kondisi } \\
\text { yang baik yang dapat } \\
\text { digunakan pengguna kursi roda } \\
\text { untuk melitasi jalur pedestrian } \\
\text { dalam kawasan transit }\end{array}$ \\
\hline & $\begin{array}{l}<34 \% \text { jalur pedestrian terdapat } \\
\text { jalur penanda khusus untuk } \\
\text { penyandang tuna netra } \\
\text { (guiding block) }\end{array}$ & $\begin{array}{l}34 \% \text { - } 67 \% \text { jalur pedestrian } \\
\text { terdapat jalur penanda khusus } \\
\text { untuk penyandang tuna netra } \\
\text { (guiding block) }\end{array}$ & $\begin{array}{l}>67 \% \text { jalur pedestrian terdapat } \\
\text { jalur penanda khusus untuk } \\
\text { penyandang tuna netra (guiding } \\
\text { block) }\end{array}$ \\
\hline $\begin{array}{l}\text { Keamanan jalur } \\
\text { pedestrian }\end{array}$ & $\begin{array}{l}<34 \% \text { Jalur pedestrian } \\
\text { terdapat penyangga/ pelindung } \\
\text { yang dapat melindungi } \\
\text { pengguna jalur pedestrian dari } \\
\text { aktivitas kendaraan bermotor }\end{array}$ & $\begin{array}{l}34 \% \text { - } 67 \% \text { Jalur pedestrian } \\
\text { terdapat penyangga/pelindung } \\
\text { yang dapat melindungi } \\
\text { pengguna jalur pedestrian dari } \\
\text { aktivitas kendaraan bermotor }\end{array}$ & $\begin{array}{l}>67 \% \text { Jalur pedestrian terdapat } \\
\text { penyangga/pelindung yang } \\
\text { dapat melindungi pengguna } \\
\text { jalur pedestrian dari aktivitas } \\
\text { kendaraan bermotor }\end{array}$ \\
\hline
\end{tabular}


Analisis skoring yang digunakan menggunakan 3 pilihan skoring, yaitu skor 1 untuk kategori tidak siap, skor 2 untuk kategori belum siap dan skor 3 untuk kategori siap dengan perhitungan interval sebagai berikut:

$$
\begin{aligned}
\text { Interval } & =(\text { nilai max }- \text { nilai min }) / 3 \\
& =(39-13) / 3=8,6 \approx 9
\end{aligned}
$$

Selanjutnya didapatkan interval nilai untuk setiap kategori, yaitu:

- $\quad$ Kategori tidak siap jika, $10<$ nilai total $<17$

- Kategori belum siap jika, $17<$ nilai total $<23$

- Kategori siap jika, $23<$ nilai total $<30$

\section{HASIL DAN PEMBAHASAN}

\subsection{JARAK BERJALAN KAKI DI KAWASAN TRANSIT}

Berdasarkan hasil skoring, variabel jarak berjalan kaki pada jalur pedestrian mendapatkan skor 1,67. Skor tersebut didapatkan dari kondisi eksisting yang menunjukan bahwa untuk menuju titik transit melalui jalur Jl. Popda - Jembatan Tirtonadi - Jl. A. Yani menempuh jarak $252 \mathrm{~m}$ (skor 3), melalui jalur Jl. A. Yani menempuh jarak $530 \mathrm{~m}$ (skor 2) dan melalui jalur Jl. Letjen S. Parman - Jl. A. Yani menempuh jarak 764 m (skor 2) (lihat Gambar 2). Skor ketiga ruas selanjutnya diakumulasi dan dirata-rata sehingga mendapat skor akhir 1,67.

Salah satu faktor yang mempengaruhinya ialah karena jalan ruas JI. A.Yani dan JI.Popda - Jembatan Tirtonadi merupakan jalan nasional, yang penanganannya dilakukan oleh Kementerian Perhubungan. Pada tahun 2018 - 2019 sedang berlangsung proyek peningkatan kualitas jalur pedestrian pada ruas Jl. Popda - Jembatan Tirtonadi yang dibawahi langsung oleh Kementerian Perhubungan. Detail Engineering Design (DED) proyek peningkatan kualitas jalur pedestrian pada ruas $\mathrm{Jl}$. Popda menunjukan panjang jalur pedestrian yang dilakukan peningkatan kualitas hanya sampai pada kondisi eksisting sekarang, namun kedepannya ada rencana untuk melanjutkan dan memperpanjang jalur pedestrian di Jl. Popda.
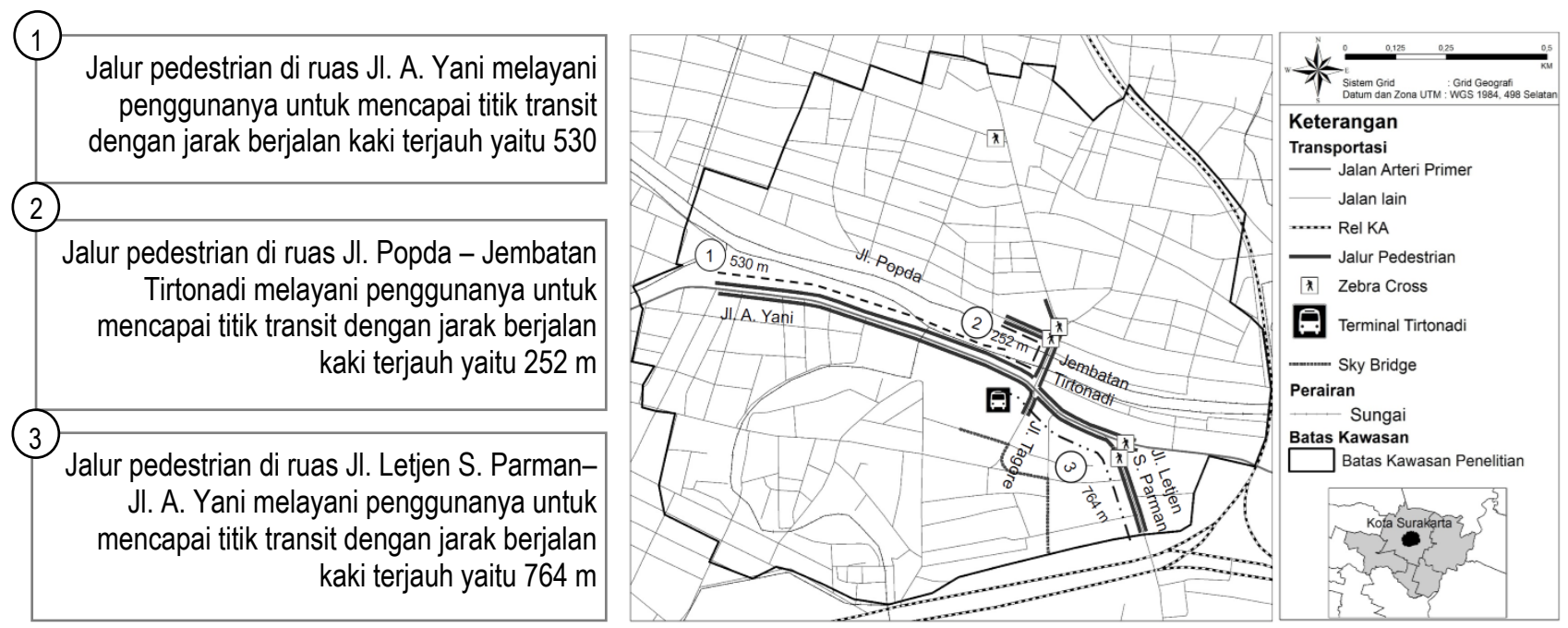

Gambar 2. Peta Jarak Berjalan Kaki di Kawasan Transit

\subsection{VARIASI RUTE JALUR PEDESTRIAN}

Berdasarkan hasil skoring, variabel variasi rute jalur pedestrian mendapatkan skor 3 , karena untuk mencapai jalur pedestrian di kawasan transit Terminal Tirtonadi dapat di tempuh dari beragam rute, yaitu jalur pedestrian pada ruas $\mathrm{Jl}$. A. Yani dapat ditempuh dari 7 variasi rute berjalan kaki, pada ruas Jl. Letjen S Parman dapat ditempuh dari 2 variasi rute berjalan kaki dan pada ruas jembatan tirtonadi dapat ditempuh dari 5 variasi rute berjalan kaki (lihat Gambar 3). Banyaknya variasi rute di kawasan transit Terminal Tirtonadi dipengaruhi oleh faktor lokasi jalur pedestrian yang berada di pusat kawasan transit. 


\subsection{TATA LETAK ATRIBUT JALUR PEDESTRIAN}

Berdasarkan hasil skoring, variabel tata letak jalur pedestrian di kawasan transit Terminal Tirtonadi mendapatkan skor 1, karena jalur pedestrian tidak dilengkapi dengan marka, perambuan, dan papan informasi (signage) khusus jalur pedestrian di sepanjang ruas jalur pedestrian. Jalur pedestrian pada ruas Jl. A. Yani, Jl. Letjen S Parman dan Jembatan Tirtonadi ketiganya tidak dilengkapi marka, perambuan dan papan informasi khusus jalur pedestrian, pada ruas tersebut hanya terdapat marka jalan dan papan informasi lalu lintas pada umumnya, bukan khusus sebagai petunjuk jalur pedestrian (lihat Gambar 4).

Jika melihat dari segi perencanaan, jalur pedestrian pada ruas Terminal Tirtonadi - Jl. Popda telah dilaksanakan proyek peningkatan kualitas jalur pedestrian pada tahun 2018 - 2019 dan Detail Engineering Design (DED) proyek tersebut telah tersedia, namun fakta di lapangan menunjukan jika jalur pedestrian belum dilengkapi oleh tata informasi khusus jalur pedestrian. Diharapkan pada masa evaluasi pasca proyek, dapat dipertimbangkan untuk menambahkan tata informasi jalur pedestrian.

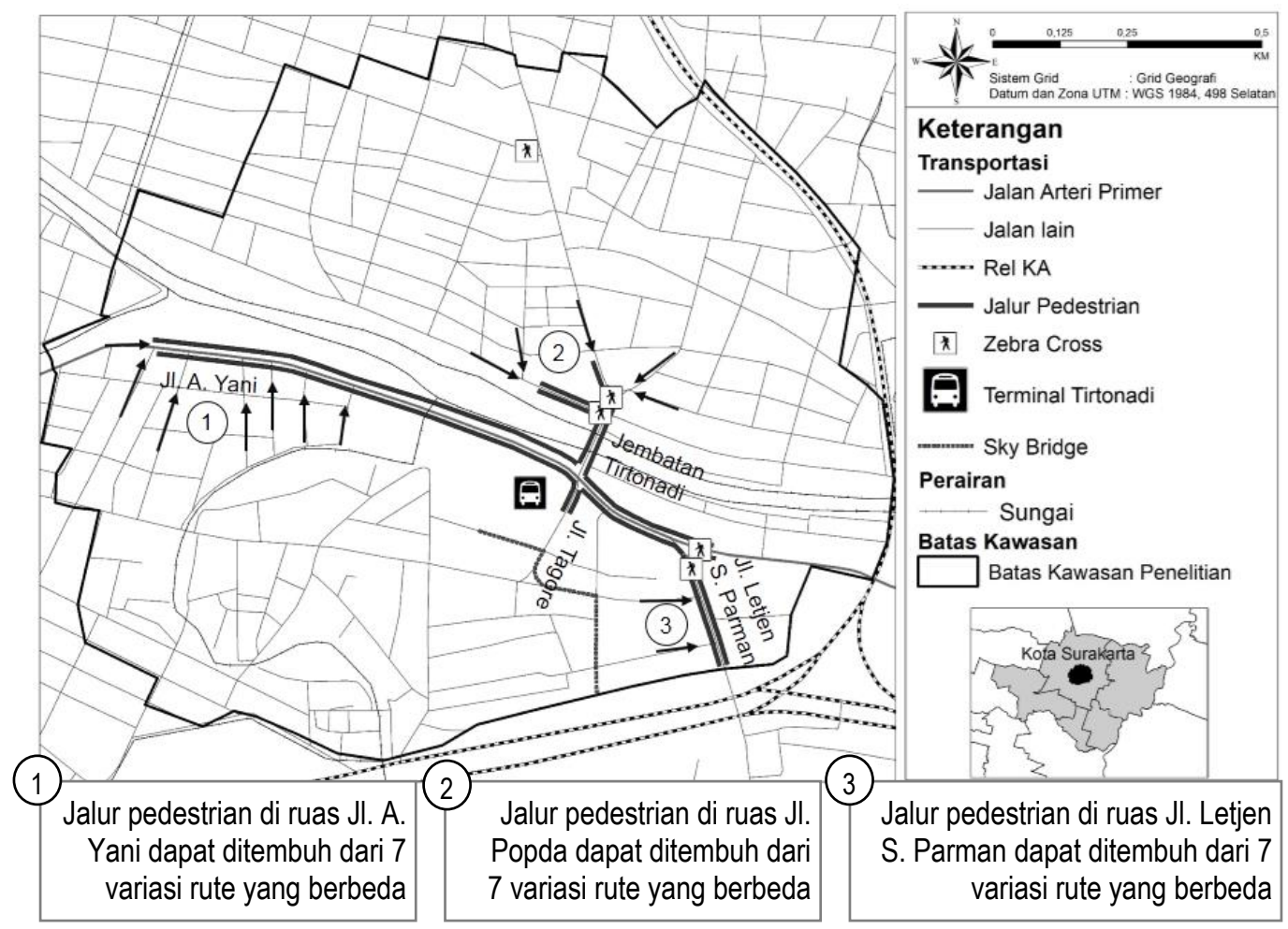

Gambar 3. Peta Variasi Rute Berjalan Kaki di Kawasan Transit

\subsection{KETERSEDIAAN ATRIBUT JALUR PEDESTRIAN}

Berdasarkan hasil skoring, variabel ketersediaan atribut jalur pedestrian di kawasan transit Terminal Tirtonadi mendapatkan nilai 1,67. Perolehan tersebut diperoleh karena kondisi atribut jalur pedestrian yang berbeda-beda di tiap ruas jalan (lihat Gambar 4). Jalur pedestrian pada ruas Jl. A. Yani tidak terdapat atribut jalur pedestrian sama sekali (skor 1). Untuk jalur pedestrian pada ruas JI. Letjen S. Parman juga tidak terdapat atribut jalur pedestrian sama sekali (skor 1). Hal sangat berbeda kita temui pada jalur pedestrian di ruas Jembatan Tirtonadi, karena jalur pedestrian di ruas tersebut sudah dilengkapi atribut berupa lampu penerangan jalan dan pagar pengaman dalam kondisi yang baik dan dapat berfungsi sebagaimana mestinya (skor 3).

Perbedaan antara jalur pedestrian di ruas Jembatan Tirtonadi dengan jalur pedestrian di ruas Jl. A. Yani dan Jl. Let. S. Parman dapat terjadi karena, pada tahun 2018-2019 sedang dilakukan pekerjaan peningkatan kualitas jalur pedestrian oleh Kementerian Perhubungan pada lokasi Jembatan Tirtonadi - Jl. Popda. Peningkatan kualitas tersebut dapat terealisasi setelah melalui tahapan pengajuan proyek yang panjang, hingga terbentuknya Detail Engineering Design (DED) dari proyek peningkatan kualitas jalur pedestrian di Jembatan Tirtonadi - J. Popda. 


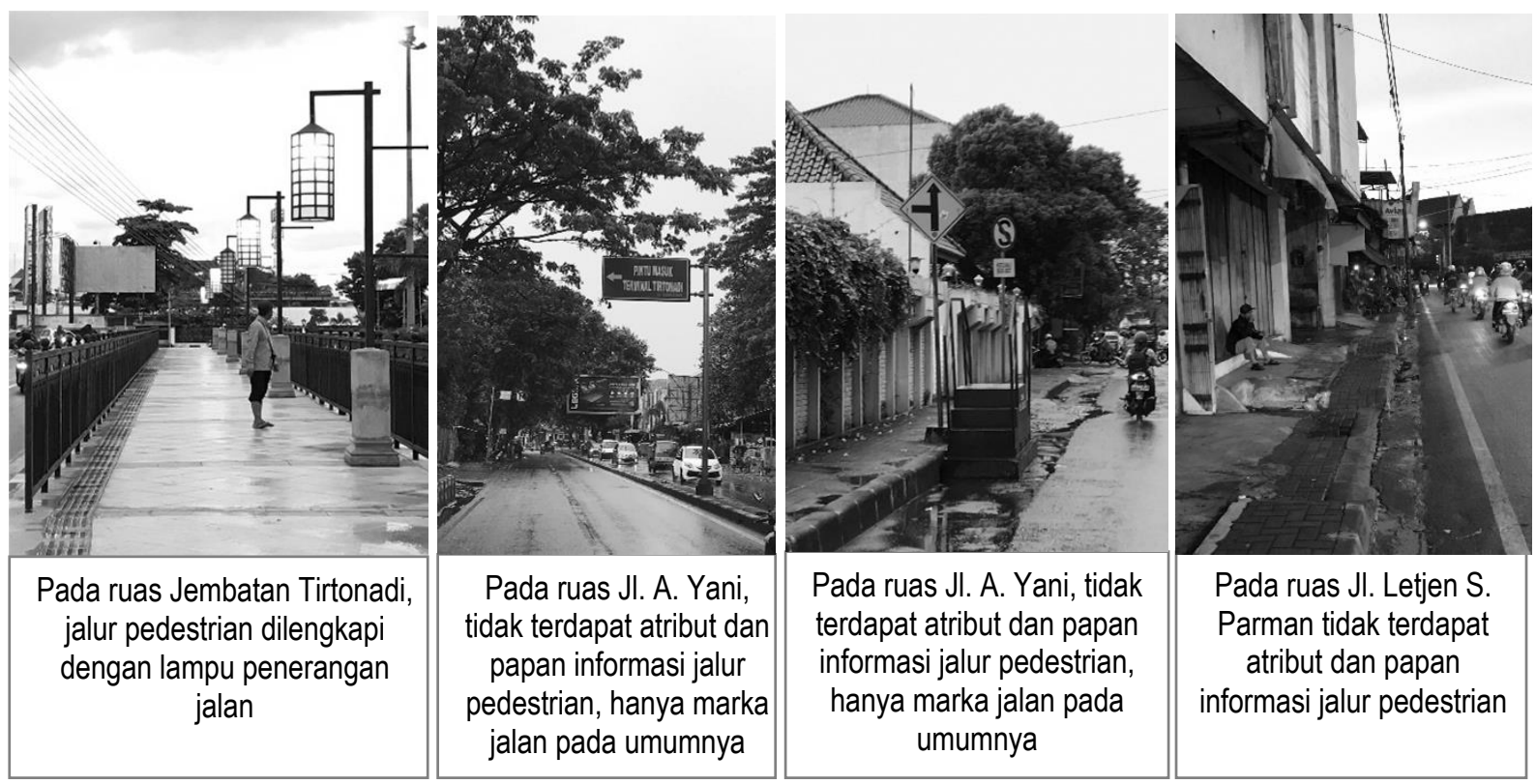

Gambar 4. Kondisi Atribut dan Tata Informasi Jalur Pedestrian di Kawasan Transit Terminal Tirtonadi

\subsection{JENIS KEBERLANGSUNGAN JALUR PEDESTRIAN}

Jenis kelangsungan jalur pedestrian yang dimaksud dalam penelitian ini ialah ditinjau dari keterhubungan jalur pedestrian dengan jalan lingkungan di kawasan hunian dan cakupan kawasan komersil yang terlayani jalur pedestrian. Berdasarkan hasil skoring, variabel kelangsungan jalur pedestrian memperoleh skor 1,83.

Keterhubungan jalur pedestrian dengan jalan lingkungan/jalan setapak di kawasan hunian mendapatkan skor 1,67, skor tersebut didapat berdasarkan kondisi eksisting yang menunjukan bahwa jalur pedestrian pada ruas Jl. A. Yani dan ruas Jl. Letjen S. Parman sudah terhubung dengan jalan lingkungan pada kawasan hunian di sekitarnya, namun tidak melayani hingga dalam kawasan hunian dan harus berjalan kaki terlebih dahulu untuk mencapainya (skor 2). Kondisi berbeda ditemui di jalur pedestrian pada ruas Jembatan Tirtonadi - Jl. Popda (lihat Gambar 5), jalur pedestrian pada ruas itu tidak terhubung hingga jalan lingkungan pada kawasan hunian, selain karena penggunaan lahan di sekitar ruas JI. Popda ialah perdagangan dan jasa, panjang jalur pedestrian di ruas Jl. Popda tidak begitu panjang, oleh karenanya belum dapat melayani hingga kawasan hunian (skor 1).

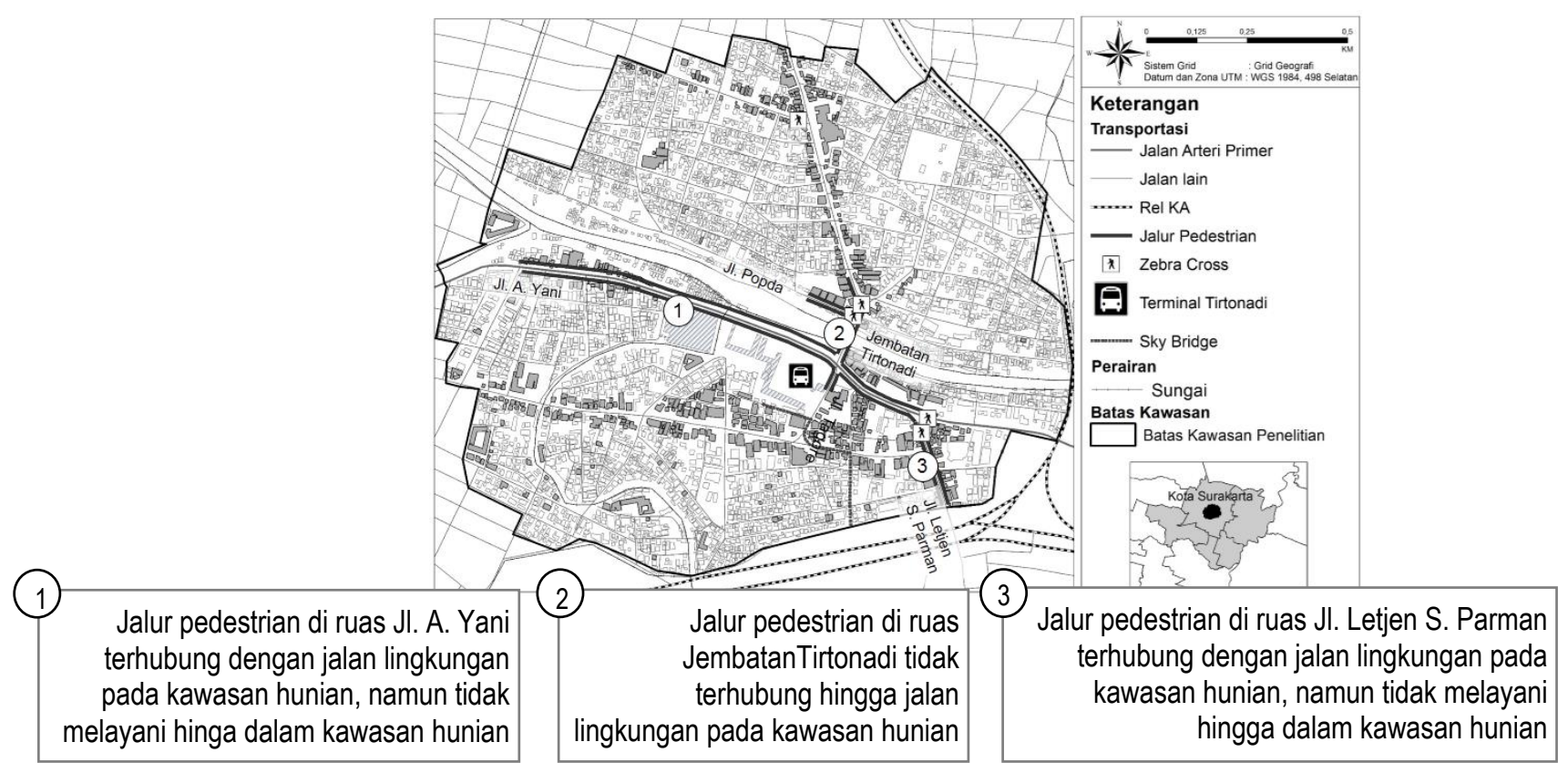

Gambar 5. Peta Jangkauan Jalur Pedestrian terhadap Jalan Lingkungan dalam Kawasan Hunian 
Untuk cakupan kawasan komersil yang terlayani jalur pedestrian mendapatkan skor 2, skor tersebut didapat dari hasil yang menujukan sekitar $57,4 \%$ kawasan komersil di kawasan transit Terminal Tirtonadi tidak terlayani oleh jalur pedestrian (lihat Gambar 6) dan berarti hanya 42,6\% kawasan komersil yang terlayani oleh jalur pedestrian. Dapat dilihat jika kawasan komersil pada ruas JI. Tagore, Jl. Adi Sumarmo, ruas Jl. Kapt. P. Tendean dan ruas Jl. Setiabudi tidak terdapat jalur pedestrian. Padahal, kondisi di lapangan menunjukan jika kawasan komersil pada ruas Jl. Setiabudi dan ruas $\mathrm{Jl}$. Kapt. P. Tendean memiliki intensitas aktivitas ruang yang tinggi dan mobilitas masyarakat yang juga tinggi, sehingga jalur pedestrian sangat dibutuhkan pada ketiga ruas tersebut. Ruas Jl. Tagore bahkan berada di sebelah Terminal Tirtonadi, yang berperan sebagai titik transit, sehingga sangat dibutuhkan jalur pedestrian.
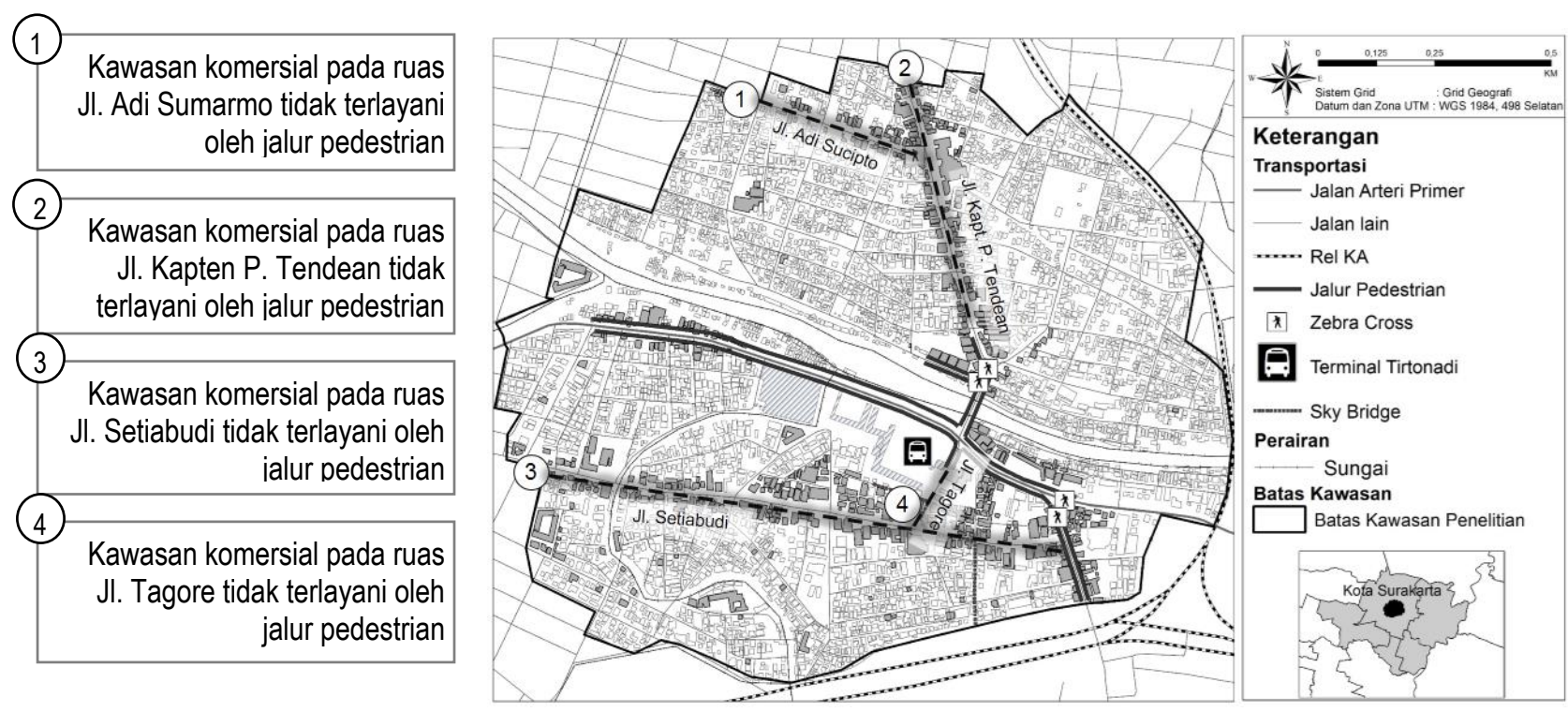

Gambar 6. Peta Kawasan Komersil yang Tidak Terlayani Jalur Pedestrian

Skor yang didapat dari keterhubungan jalur pedestrian dengan jalan lingkungan di kawasan hunian dan cakupan kawasan komersil yang terlayani jalur pedestrian selanjutnya dirata-rata dan menghasilkan skor akhir untuk variabel jenis kelangsungan jalur pedestrian yaitu sebesar 1,56. Jauhnya jarak yang harus ditempuh untuk mencapai jalur pedestrian dapat dipengaruhi oleh faktor lokasi jalur pedestrian yang hanya berada di pinggir jalan raya dan terletak di tengah kawasan transit. Panjang jalur pedestrian yang tidak terlalu panjang juga menjadikan jalur pedestrian belum dapat menjangkau seluruh kawasan transit. Hal itu juga dipengaruhi oleh ketersediaan anggaran yang dimiliki oleh pemerintah, sehingga dalam melakukan proyek pembangunan jalur pedestrian umumnya harus dilaksanakan secara bertahap.

\subsection{NILAI STRATEGIS LOKASI JALUR PEDESTRIAN}

Berdasarkan hasil skoring, variabel nilai strategis jalur pedestrian mendapatkan skor 3. Skor tersebut didapat karena jalur pedestrian di kawasan transit Terminal Tirtonadi terletak pada daerah yang banyak dilalui masyarakat sebagai tempat transit dan didukung oleh kantong parkir yang terletak di dalam Terminal Tirtonadi. Sebagai pusat transit bus, kawasan transit Terminal Tirtonadi dilewati oleh feeder Batik Solo Trans (BST) koridor 4, 6, 8, 11, 12 dan 13 yang bisa mempermudah mobilisasi masyarakat ke berbagai lokasi di Kota Surakarta.

\subsection{PENGARUH FAKTOR IKLIM}

Berdasarkan hasil skoring, variabel pengaruh faktor iklim mendapatkan skor 2. Hasil tersebut didapatkan dari kondisi pohon atau kanopi bangunan sekitar yang dapat dijadikan sebagai tempat berteduh. Kondisi di tiap ruas jalur pedestrian berbeda-beda (lihat Gambar 7), pada ruas J. A. Yani terdapat pohon-pohon yang rindang dan dapat berfungsi sebagai peneduh jalur pedestrian (skor 3). Sedangkan jalur pedestrian pada ruas Jl. Letjen S. Parman tidak terdapat pohonpohon peneduh, tetapi terdapat kanopi bangunan sekitar yang dapat digunakan sebagai tempat berteduh meskipun tidak tersedia di seluruh jalur pedestrian (skor 2). Hal berbeda ditemui pada jalur pedestrian di ruas Jembatan Tirtonadi Jl. Popda yang tidak terdapat pohon atau kanopi bangunan sekitar yang dapat dijadikan tempat berteduh (skor 1). Skor yang diperoleh di tiap ruas selanjutnya diakumulasi dan dirata-rata, sehingga mendapatkan skor akhir 2. 


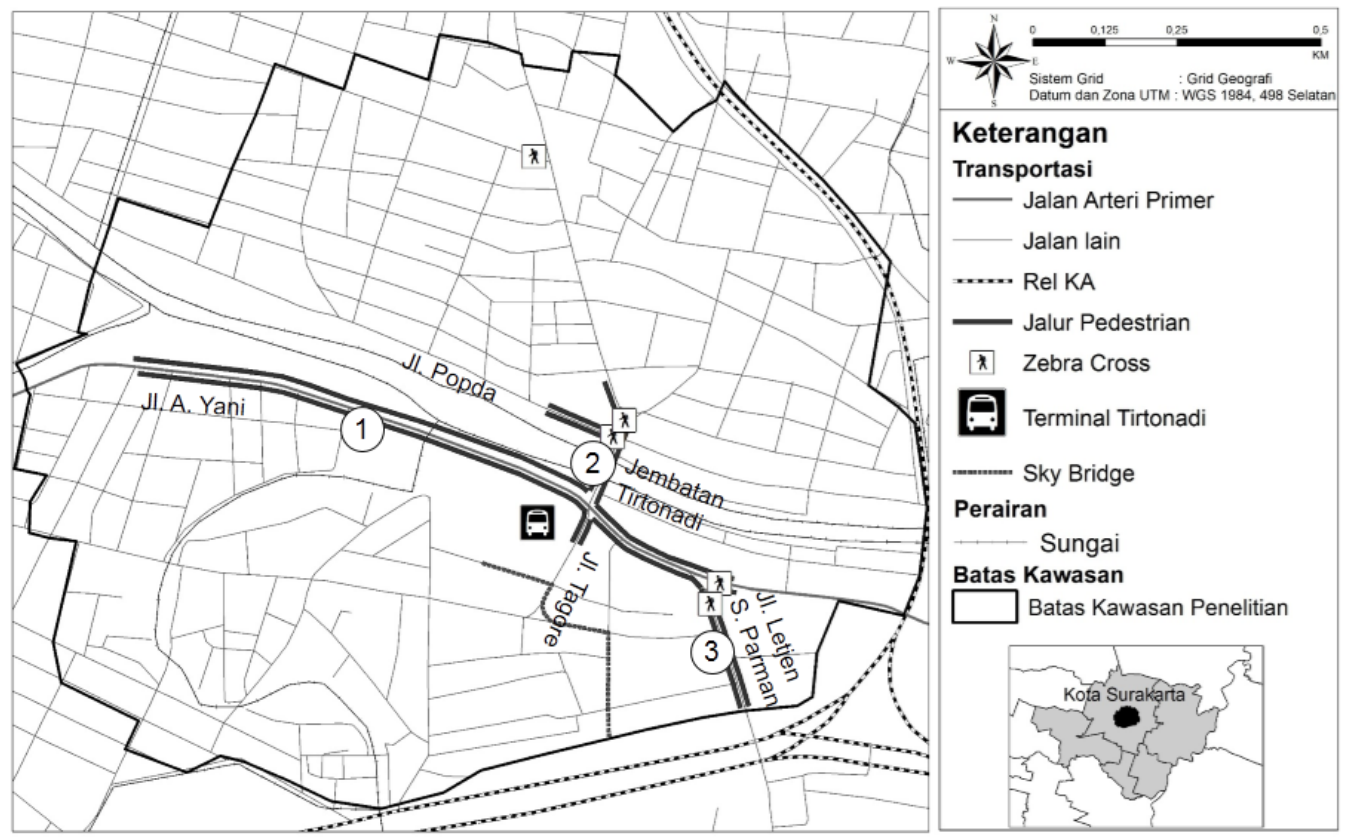

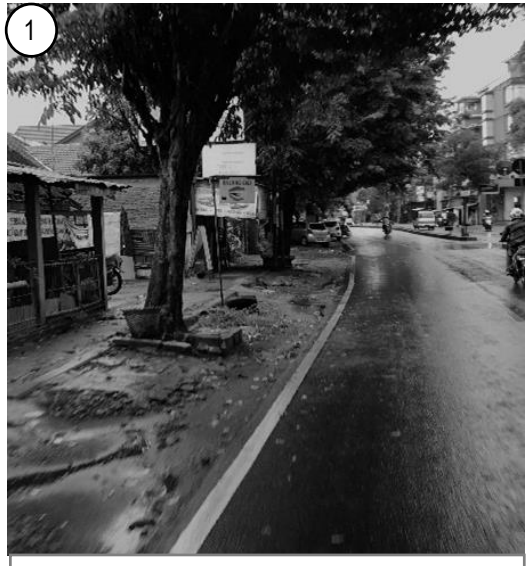

Pepohonan pada ruas Jl. A. Yani dapat memberi keteduhan pada jalur pedestrian

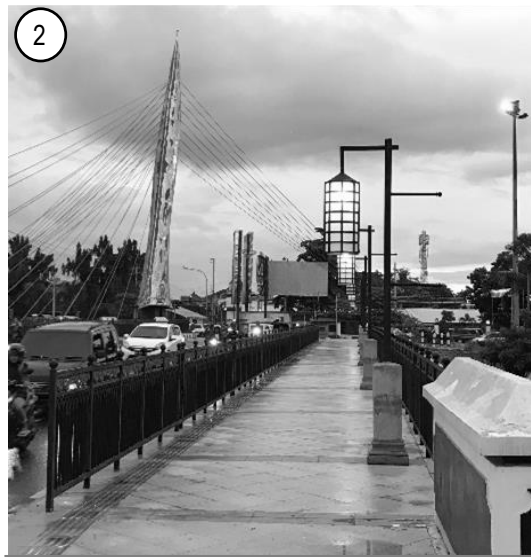

Ruas jembatan tirtonadi tidak terdapat pohon atau kanopi bangunan sekitar yang dapat dijadikan sebagai peneduh jalur pedestrian

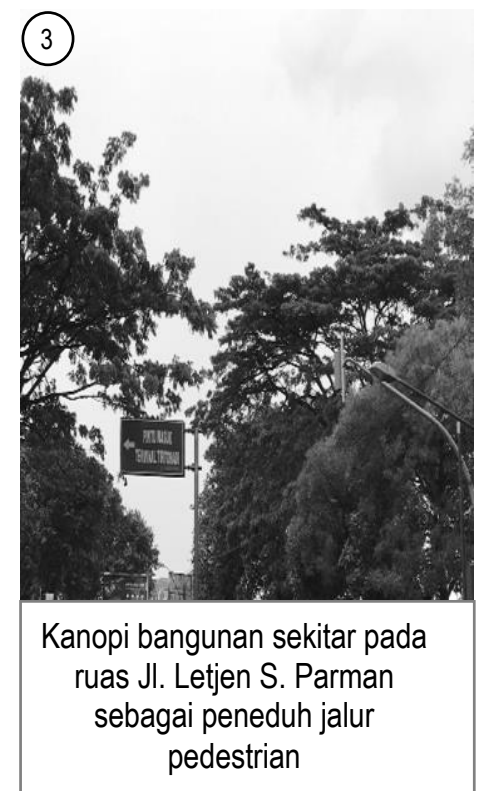
pedestrian

Gambar 7. Kondisi Peneduh Jalur Pedestrian di Kawasan Transit Terminal Tirtonadi

\subsection{ASPEK KENYAMANAN BAGI DISABILITAS}

Berdasarkan hasil skoring, variabel aspek kenyamanan bagi disabilitas mendapatkan skor 1. Hasil tersebut diperoleh dari persentase jalur pedestrian yang terbebas oleh penghalang seperti tiang, pohon, parkir dan/atau atribut lainnya dan bebas pembatas sehingga pengguna kursi roda dapat melintas dengan mudah. Kondisi jalur pedestrian pada ruas Jembatan Tirtonadi - Jl. Popda bebas dari penghalang, sehingga pengguna kursi roda dapat melintas dengan mudah. Namun kondisi berbeda ditemui pada jalur pedestrian di ruas Jl. A. Yani dan Jl. Letjen S. Parman. Kondisi jalur pedestrian di kedua ruas tersebut terhalang oleh tiang, pohon dan atribut lainnya, sehingga pengguna kursi roda tidak dapat melintas (lihat Gambar 8). Dengan kata lain, sekitar 67\% jalur pedestrian terhalang oleh penghalang dan pembatas, sehingga hanya sekitar 33\% jalur pedestrian yang bebas penghalang dan bebas pembatas sehingga kursi roda dapat melintas dengan mudah. 


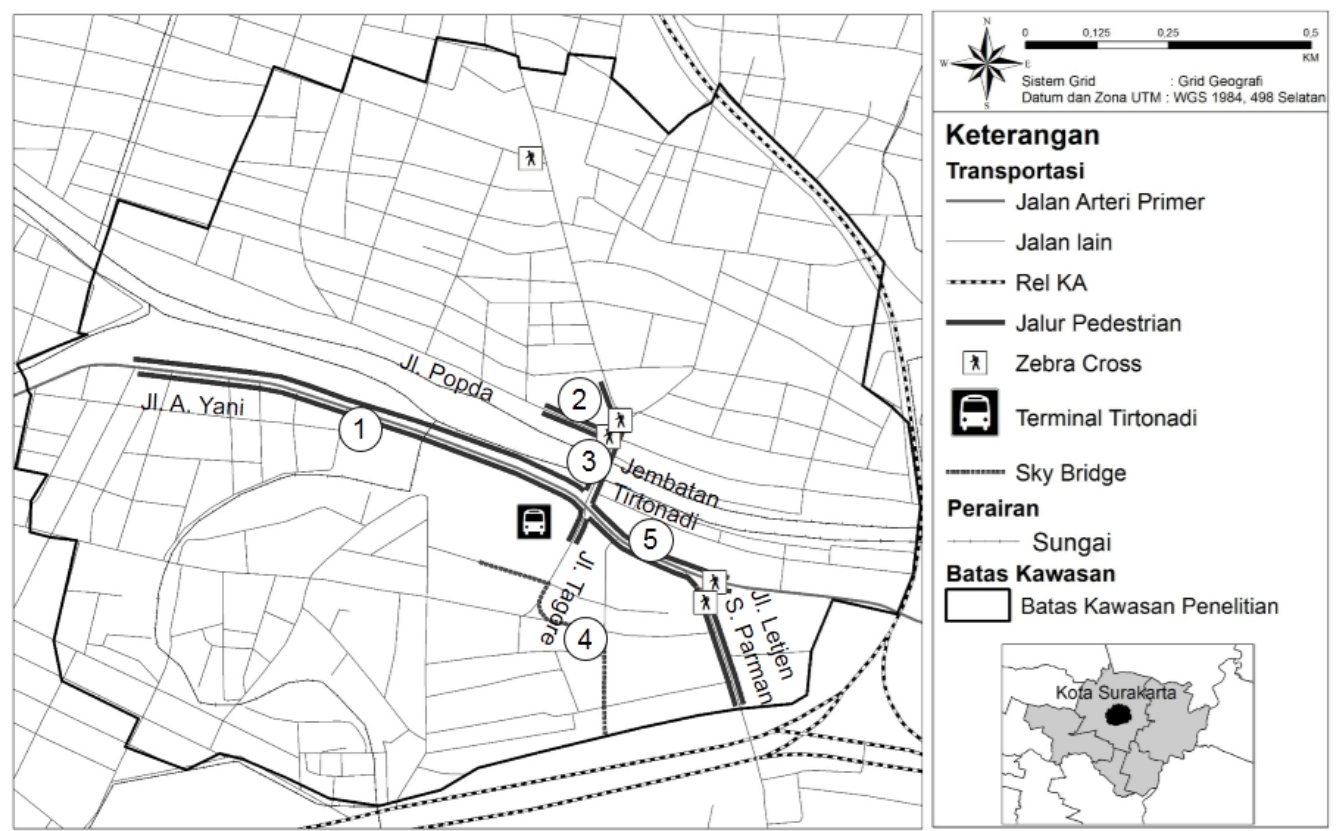

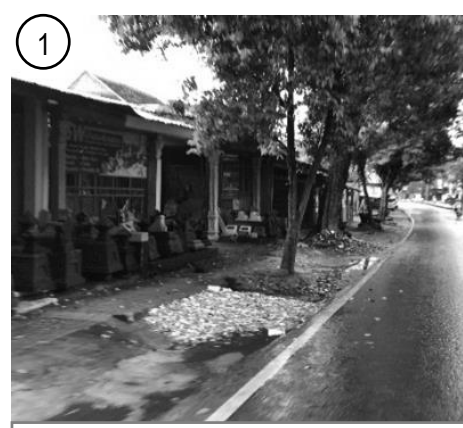

Bagian alur pedestrian pada ruas JI. A. Yani terhalang oleh barang-barang jualan dan pohon

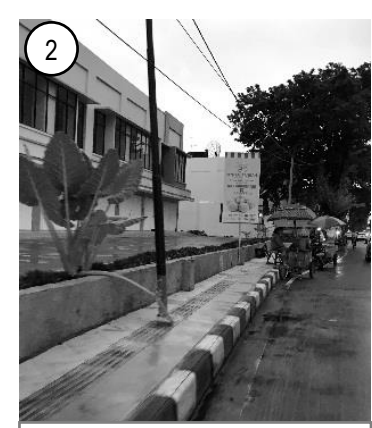

Bagian jalur pedestrian baru pada ruas $\mathrm{Jl}$. Popda terhalang oleh tiana listrik

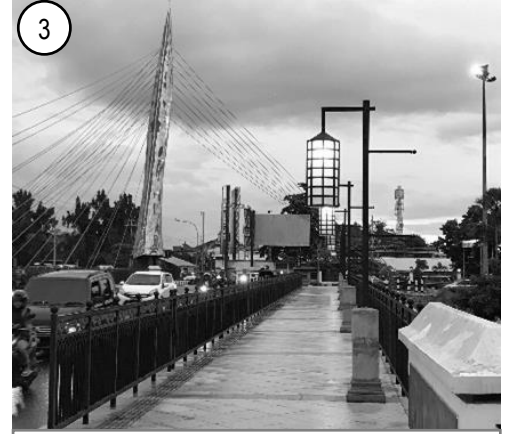

Jalur pedestrian pada ruas Jembatan Tirtonadi bebas penghalang

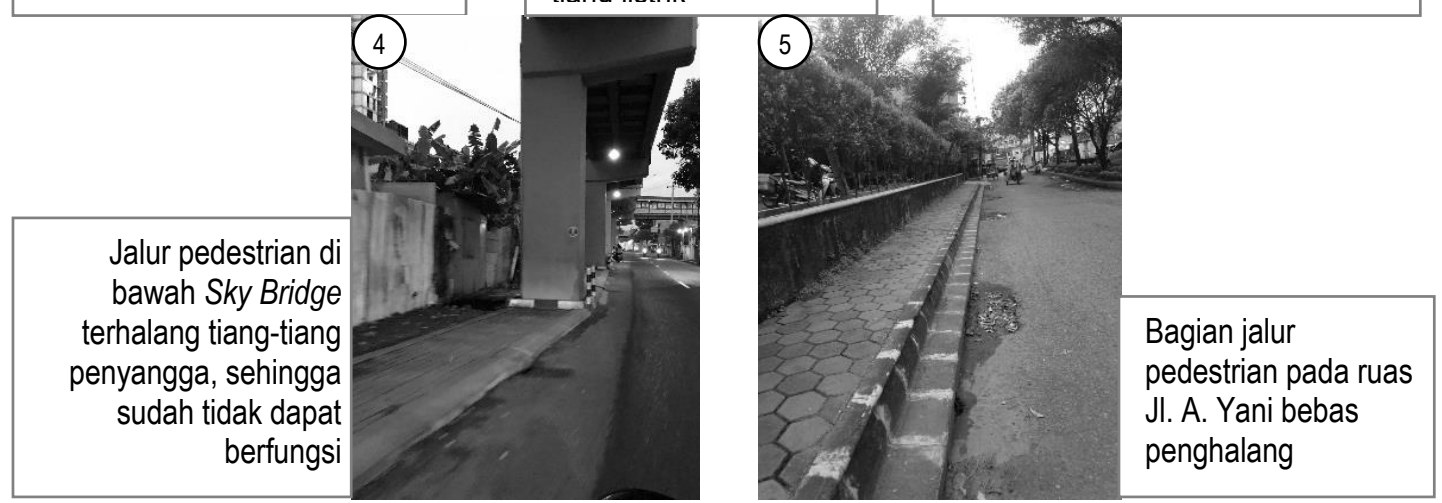

Gambar 8. Lokasi dan Kondisi Hambatan Jalur Pedestrian

\subsection{ASPEK KEMUDAHAN BAGI DISABILITAS}

Berdasarkan hasil skoring, variabel aspek kemudahan bagi disabilitas mendapatakan skor 1,16. Hasil tersebut diperoleh dari penilaian terhadap ketersediaan dan kondisi ramp serta persentase guiding block pada jalur pedestrian. Kondisi eksisting menunjukan jika jalur pedestrian pada ruas JI. A. Yani dan Jembatan Tirtonadi - Jl. Popda tidak dilengkapi dengan ramp sehingga pengguna kursi roda tidak dapat menggunakan jalur pedestrian (skor 1), sedangkan 
jalur pedestrian pada ruas Jl. Letjen S. Parman dilengkapi dengan ramp, namun dalam kondisi yang buruk/rusak sehingga pengguna kursi roda tidak dapat menggunakan jalur pedestrian (skor 2).

Jalur pedestrian yang dilengkapi dengan guiding block hanya terdapat di jalur pedestrian pada ruas Jl. Popda, berarti hanya sekitar $28 \%$ jalur pedestrian di kawasan transit Terminal Tirtonadi yang terdapat guiding block dalam keadaan baik sehingga mendapat skor 1 . Untuk mendapatkan skor akhir, skor ketersediaan dan kondisi ramp dengan skor persentase guiding block diakumulasi dan dirata-rata, sehingga mendapatkan skor akhir 1,16. Kondisi ketersediaan guiding block yang hanya ditemui pada jalur pedestrian di ruas Jl. Popda disebabkan karena ketentuan untuk menyediakan guiding block terdapat di dalam Detail Engineering Design (DED) proyek peningkatan kualitas jalur pedestrian di Jembatan Tirtonadi - Jl. Popda.

\subsection{KEAMANAN JALUR PEDESTRIAN}

Berdasarkan hasil skoring, variabel keamanan jalur pedestrian mendapatkan skor 1. Hasil tersebut diperoleh dari persentase jalur pedestrian yang memiliki penyangga/pelindung jalur pedestrian. Kondisi eksisting menunjukan bahwa jalur pedestrian pada ruas JI. Letjen S. Parman, ruas JI. A. Yani dan ruas J. Popda tidak terdapat penyangga/ pelindung baik pagar pembatas ataupun pohon (lihat Gambar 9 a dan $\mathrm{c}$ ), sehingga pengguna jalur pedestrian tidak terlindungi dari aktivitas kendaraan bermotor. Jalur pedestrian pada ruas Jembatan Tirtonadi sudah dilengkapi dengan pagar pembatas jalur pedestrian dengan jalan raya (lihat Gambar 9 b), sehingga pengguna terlindungi dari aktivitas kendaraan bermotor. Dengan kata lain, hanya sekitar $28 \%$ jalur pedestrian yang terdapat penyangga/pelindung.

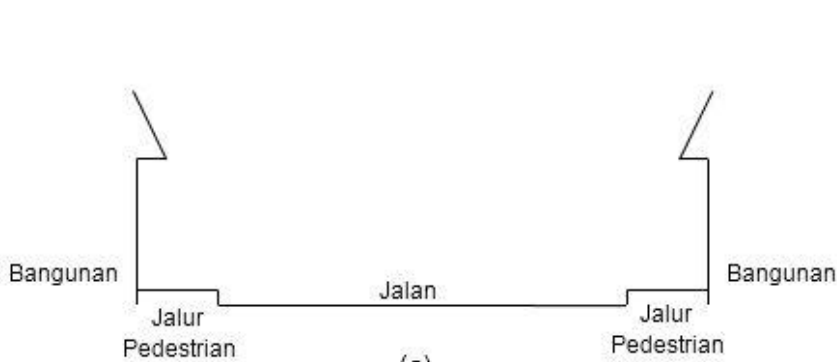

(a)

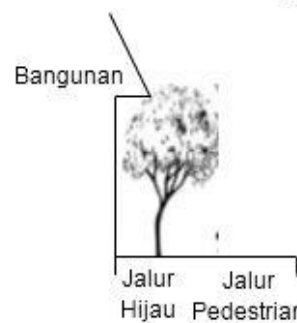

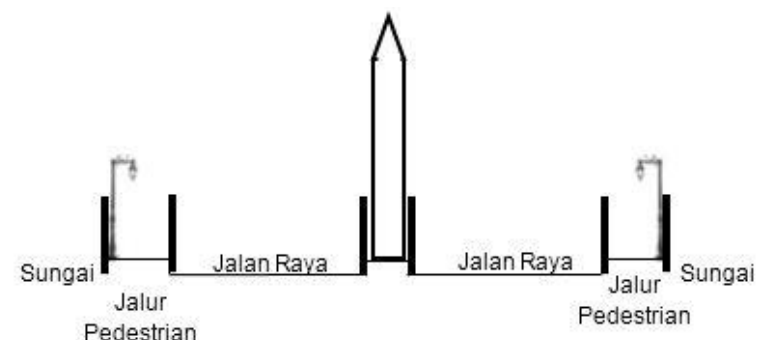

(b)

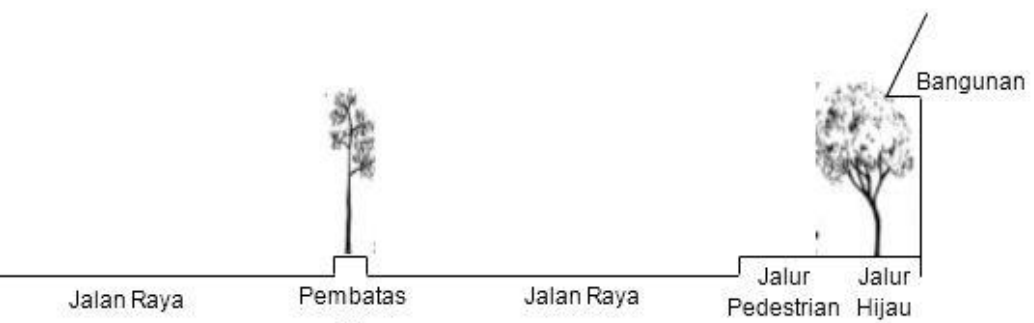

(c)

Gambar 9. Penampang Jalur Pedestrian

\section{KESIMPULAN}

Terdapat tiga ruas jalur pedestrian di kawasan transit Terminal Tirtonadi, yaitu jalur pedestrian pada ruas Jl. A. Yani, ruas JI. Popda - Jembatan Tirtonadi dan ruas Jl. Letjen S. Parman. Berdasarkan hasil akumulasi skor dari variabelvariabel yang digunakan, didapatkan hasil sebesar 17,33 yang berarti bahwa aksesibilitas jalur pedestrian di kawasan transit Terminal Tirtonadi belum siap sebagai jalur pedestrian berdasarkan konsep TOD. Hal tersebut menunjukan jika aksesibilitas di ketiga ruas jalur pedestrian kawasan transit Terminal Tirtonadi belum mampu untuk memenuhi kriteriakriteria dari konsep TOD. Terdapat kesenjangan (gap) antara kondisi eksisting jalur pedestrian dengan kriteria konsep TOD, sehingga diperlukan upaya-upaya untuk mengurangi atau bahkan menghilangkan gap tersebut.

Pada tahun 2018-2019 dilakukan proyek peningkatan kualitas jalur pedestrian oleh Kementerian Perhubungan pada ruas JI. Popda - Jembatan Tirtonadi, sehingga kondisi jalur pedestrian pada ruas Jl. Popda - Jembatan Tirtonadi secara umum terlihat jauh lebih baik daripada kondisi jalur pedestrian pada ruas JI. A. Yani dan ruas Jl. Letjen S. Parman. Penilaian kesiapan dalam penelitian ini dapat memberi rekomendasi peluang untuk memperbaiki gap atau kesenjangan yang timbul, oleh karena itu diperlukan upaya peningkatan kualitas dan penambahan kuantitas jalur pedestrian di kawasan ini agar dapat mencapai kategori siap sebagai jalur pedestrian berdasarkan konsep TOD. 
Upaya peningkatan kualitas jalur pedestrian utamanya dilakukan pada ruas Jl. A. Yani dan Jl. Letjen S. Parman, karena jalur pedestrian sudah tersedia namun dalam kondisi yang kurang baik. Kondisi di lapangan menunjukan bahwa jalur pedestrian pada kedua ruas tersebut tidak dilengkapi marka, perambuan dan papan informasi khusus jalur pedestrian. Kondisi dan ketersediaan peneduh seperti pohon/kanopi bangunan belum merata. Jalur pedestrian belum semuanya terhubung dengan jalan lingkungan di kawasan hunian, belum mencakup seluruh kawasan komersil dan jarak tempuh untuk mencapai jalur pedestrian yang cukup panjang. Jalur pedestrian belum dilengkapi dengan penyangga/pelindung untuk melindungi pejalan kaki. Pohon, tiang dan parkir menghalagi jalur pedestrian dan tidak terdapat guiding block dan ramp bagi pengguna disabilitas.

Sedangkan, upaya penambahan kuantitas jalur pedestrian utamanya dilakukan pada Jl. Popda, Jl. Tagore, Jl. Setiabudi, Jl. Adisucipto dan JI. Kapt. P. Tendean, karena ruas-ruas tersebut berada dalam kawasan komersil dengan aktivitas berjalan kaki yang intensif, oleh karena itu jalur pedestrian sangat dibutuhkan. Penambahan kuantitas jalur pedestrian tentunya dengan menambahkan jalur pedestrian yang sesuai dengan kriteria TOD, yaitu jarak berjalan kaki dalam jalur pedestrian yang pendek $(<800 \mathrm{~m})$, jalur pedestrian dilengkapi dengan atribut (seperti marka, perambuan, papan informasi khusus jalur pedestrian, dll.) dengan tata letak yang tidak menghalangi, didukung oleh pohon atau kanopi bangunan sekitar yang dapat dijadikan sebagai tempat berteduh, serta dilengkapi dengan guiding block dan ramp bagi pengguna disabilitas. Jalur pedestrian juga diupayakan terhubung dengan jalan lingkungan di kawasan hunian, melayani kawasan komersil dan jarak untuk mencapai jalur pedestrian yang pendek (<400 m).

Diharapkan ada penanganan lebih lanjut dari stakeholder terkait, mengenai jalur pedestrian di kawasan transit Terminal Tirtonadi mengingat Terminal Tirtonadi merupakan terminal yang akan dikembangkan di bidang komersial melalui konsep TOD sekaligus dijadikan pilot project pengembangan terminal berbasis konsep TOD oleh Dirjen Perhubungan Darat Kementerian Perhubungan RI.

\section{UCAPAN TERIMA KASIH}

Ucapan terimakasih penulis sampaikan kepada dosen pembimbing, dosen penguji, reviewer, narasumber, Dinas PUPR Kota Surakarta, surveyor dan Program Studi Perencanaan Wilayah dan Kota, Fakultas Teknik, Universitas Sebelas Maret karena telah membantu dan mendukung proses pembuatan penelitian ini.

\section{DAFTAR PUSTAKA}

Conesa, A. (2018). The Accessibility Assessment and The Regional Range of Transit-Oriented Development: An application of Schedule Accessibility Measures in the Nord Pas-de-Calais region. The Jurnal of Transport and Land Use, 11(1), 119-141. http://dx.doi.org/10.5198/jlu.2018.850

Fani. (2016). Transit - Oriented Development (TOD). Diakses dari http://www.itdp-indonesia.org/tod/transit-oriented-developmenttod/.

Florida Department of Transportation. (2012). Florida TOD Guidebook. Diakses dari http://www.fltod.com/Florida\%20TOD\%20Guidebook-sm.pdf

Handayeni, Ketut Dewi M E. (2014). TOD Best Practice: Lesson Learned for GHG Mitigation on Transportation Sector in Surabaya City, Indonesia. Procedia - Social and Behavioral Sciences, 135, 152-158. https://doi.org/10.1016/j.sbspro.2014.07.340

Hasibuan, H. S. (2014). The Role of Transit Oriented Development in Constructing Urban Environment Sustainability, the Case of Jabodetabek, Indonesia. Procedia Environmental Science, 20, 622-631. https://doi.org/10.1016/j.proenv.2014.03.075

Institute for Transportation \& Develompent Policy (ITDP) Indonesia. (2017). TOD Standard Volume 3.0. Diakses dari http://www.itdp-indonesia.org/library/tod-standard-3/

Kementerian Pekerjaan Umum (2014). Pedoman Perencanaan, Penyediaan, dan Pemanfaatan Prasarana dan Sarana Jaringan Pejalan Kaki di Kawasan Perkotaan No. 03/PRT/M/2014. Diakses dari http://pugpupr.pu.go.id/_uploads/Produk_Pengaturan/Permen\%20PUPR\%20No\%2003-2014.pdf

Kementerian Pekerjaan Umum dan Perumahan Rakyat (2018). Pedoman Perencanaan Teknis Fasilitas Pejalan Kaki No. 02/SE/M/2018. Diakses dari: http://sni.litbang.pu.go.id/image/sni/isi/pd-03---2017---b.pdf

Li, Chia-Nung, Chiang Lin, et al. (2016). TOD District Planning Based on Residents' Perspectives. ISPRS International Jurnal of Geo-Information, 5(4), 52. https://doi.org/10.3390/ijgi5040052

Metropolitan Atlanta Rapid Transit Authority (MARTA). (2010). Transit-Oriented Development Guidelines. Diakses dari https://www.itsmarta.com/uploadedFiles/More/Transit_Oriented_Development/TOD\%20Guidelines\%202010-11.pdf 
Metropolitan Council. (2006, Juni). Pedestrian-Oriented Features | Guide for Transit-Oriented Development, hal. 5. Diakses dari https://metrocouncil.org/Communities/Services/Livable-Communities-Grants/Maps,-forms-misc/Metropolitan-Council-TODGuide-Pedestrian-Oriented.asp $x$

Mondou, V. (2001). Daily Mobility and Adequacy of the Urban Transportation Network a GIS Application. European Journal of Geography, 192, 15-22. https://doi.org/10.4000/cybergeo.990

National Association of City Transportation Officials. (2008, Juni). San Francisco Better Street Plan. Diakses dari https://nacto.org/docs/usdg/better_streets_plan_san_francisco.pdf

New York City Sidewalk Guideline. (2013). Active Design: Shaping the Sidewalk Experience. Diakses dari https://www1.nyc.gov/site/planning/plans/active-design-sidewalk/active-design-sidewalk.page

Prabawati, G. (2018). Dirjen Hubdar Kemenhub: Terminal Tirtonadi Solo Jadi Pilot Project Pengembangan Terminal TOD. Solo Tribunnews. Diakses dari http://solo.tribunnews.com/2018/04/21/dirjen-hubdar-kemenhub-terminal-tirtonadi-solo-jadi-pilotproject-pengembangan-terminal-tod

U. S. Department of Health and Human Service, Health Resources and Services Administration ( $n, d)$. Readiness Assessment \& Developing Project Aims. Diakses dari https://www.hrsa.gov/sites/default/files/quality/toolbox/508pdfs/readinessassessment.pdf

Western Australia Department of Transport. (2011). Planning and Designing for Pedestrians: Guidelines. Diakses dari: https://www.transport.wa.gov.au/mediaFiles/active-transport/AT_WALK_P_plan_design_pedestrians_guidelines.pdf

Widyahari, Asti, N. L., \& Indrajaru, P. N. (2015). The Potential of Transit-Oriented Development (TOD) and Its Opportunity in Bandung Metropolitan Area. Procedia Environmental Sciences, 28, 474 - 482. https://doi.org/10.1016/j.proenv.2015.07.057 